\title{
An infant oral health programme in Goiânia-GO, Brazil: results after 3 years of establishment
}

\section{Um programa de Saúde Bucal para bebês em Goiânia-GO: resultados após 3 anos}

\author{
Marina Batista Borges Pereira* \\ Maria do Carmo Matias Freire ${ }^{* *}$
}

\begin{abstract}
The objective of this study was to describe the outcomes of an infant oral health programme 3 years after implementation, a programme focused on health education for parents and caries prevention methods for children in a baby clinic. A retrospective cohort study was carried out. The setting was the Infant Oral Health Programme developed at the baby clinic of the State Department of Health, Goiânia-GO, Brazil. The sample comprised 100 children who entered the programme from birth to 12 months and were followed for 2 to 3 years. Variables investigated were caries experience, caries risk, and children's behaviour in the dental clinic. The number of children with caries experience was 1 at the initial visit and 8 after the follow-up. There was a dramatic decrease in the number of children in the high risk group, from $51 \%$ at the initial visit to only $1 \%$ after 2 to 3 years. Children's behaviour in the dental clinic was according to their psychological development. It was concluded that the Infant Oral Health Programme in Goiânia showed positive outcomes after 3 years of establishment. Further investigations should evaluate the cost-benefit, as well as the effectiveness of the procedures used in the programme.
\end{abstract}

DESCRIPTORS: Health plans and programmes; Infant; Oral health.

RESUMO: O objetivo do presente estudo foi descrever os resultados após 3 anos de implantação de um programa odontológico para bebês, com ênfase na educação dos pais e em métodos de prevenção para as crianças. Foi realizado um estudo de coorte retrospectivo utilizando-se dados do Programa de Saúde Bucal para Bebês desenvolvido na Secretaria Estadual de Saúde de Goiânia-GO, Brasil. A amostra foi constituída de 100 crianças que freqüentaram o programa desde o nascimento até os 12 meses de idade e que foram acompanhadas durante 2 a 3 anos. As variáveis investigadas foram a experiência de cárie, o risco de cárie e o comportamento das crianças na clínica. O número de crianças com experiência de cárie foi uma na visita inicial e oito após o acompanhamento. Houve uma dramática redução no número de crianças com alto risco, de $51 \%$ na visita inicial para apenas $1 \%$ após 2 a 3 anos. O comportamento das crianças na clínica foi de acordo com o seu desenvolvimento psicológico. Concluiu-se que o Programa de Saúde Bucal para Bebês em Goiânia mostrou resultados positivos após 3 anos de implantação. Futuras investigações deveriam avaliar o custo-benefício, assim como a efetividade dos procedimentos utilizados no programa.

DESCRITORES: Planos e programas de Saúde; Lactente; Saúde Bucal.

\section{INTRODUCTION}

Epidemiological studies have shown a high prevalence of dental caries in preschool children in most economically developing countries, and among deprived populations in some developed countries ${ }^{1,17}$. The early onset of the disease is strongly related to inappropriate infant feeding practices and low socioeconomic status, among other risk factors ${ }^{19}$. This is a particularly worrying trend in developing countries, which, for economic reasons, may be unable to provide adequate levels of child dental care to treat the disease. Despite this, only a few studies have advocated oral health care for children under the age of $3^{11,15,18,21}$, and interventions are generally proposed at the individual level.

In Brazil, the only national survey including preschool children was carried out in 1993 and showed high levels of caries among children between 3 and 6 years of age ${ }^{16}$. Over the last few years, several local epidemiological studies among infants and preschool children have been done $e^{2,9}$. Although some localities have developed specific oral health programmes for this age group, and evaluation reports have been published d $^{3,5,10,13,20,22}$,

* DDS, State Secretariat of Health of Goiás.

** Associate Professor, School of Dentistry, Federal University of Goiás. 
Pereira MBB, Freire MCM. An infant oral health programme in Goiânia-GO, Brazil: results after 3 years of establishment. Braz Oral Res 2004:18(1);12-7.

there is a need for well-designed studies.

In the city of Goiânia, in the Midwest of Brazil, caries experience was high in nursery school children under 6 years of age in 1993, and was strongly associated with the socioeconomic condition of the families ${ }^{7}$. It was also found that only $20.4 \%$ of the nurseries provided some dental care ${ }^{8}$. The Infant Oral Health Programme was developed in Goiânia by the State Department of Health in 1991, aiming at promoting oral health among children under 3 years of age. Children from birth to 12 months are eligible to enter the programme and stay until they are 36 months. A baby clinic was set up, using simple, low cost and locally produced equipment, following the model proposed by Walter et al. ${ }^{21}$ (1996).

The purpose of this study was to describe the outcomes of the Infant Oral Health Programme in relation to caries experience, caries risk, and children's behaviour in the dental office, after 3 years of establishment.

\section{METHODS \\ Strategies of the programme}

Strategies of the programme included health education and preventive measures. Restorative and emergency care was also provided when needed. All parents attended 3 weekly sessions on oral health education when their children entered in the programme. After this, preventive methods and recall intervals were planned according to caries risk, which was based on oral health-related behaviours. Information was obtained through parents' interview, and included sugar intake, night bottle-feeding, oral hygiene and fluoride exposure. Children were classified into three groups for caries risk: high, moderate and low. Intervals between recall visits were 30, 45 and 60 days, respectively (Table 1).

Preventive measures were performed by dentists and hygienists. They included plaque removal and topical application of $1.23 \%$ fluoride gel at every recall visit, and sealant resin application in teeth with deep fissures. Individual advice to parents, including training on their children's oral hygiene, was also given at every recall visit. Home care, performed by parents, included plaque removal, topical application of $0.05 \%$ fluoride solution at bedtime, and dietary control. Use of toothpaste was not recommended for children under 30 months of age.

\section{Study population}

A total of 1,006 children entered the Infant Oral Health Programme developed by the State Department of Health in Goiânia-GO from February 1991 to June 1994. Of those, 483 children attended the programme for about 2 to 3 years, in the morning shift. The afternoon shift was not included in the present study, because it involved another group of professionals, and standardization of procedures was not fully obtained ${ }^{4}$. The drop-out rate was $31.9 \%$, and of the 329 children who remained in the programme, only 100 were available for evaluation 2 to 3 years later. The others (229) had attended the programme for a shorter period. Therefore, the study population comprised 100 children aged 24 to 48 months (mean age $=35.4$ months) at the time of the evaluation, $52 \%$ male and $48 \%$ female. Children came mainly from families of low socioeconomic background, living in the greater urban area.

\section{Clinical examination for dental caries}

Caries experience was assessed in the first visit (from 1991 to 1992) and 2 to 3 years later (1994) by means of clinical visual examinations. These were carried out by 4 experienced dentists, using plane mirrors, after professional plaque removal. No intra or interexaminer calibration was carried out. Carious lesions were recorded using the dmft index (decayed, missing or filled teeth), and bite-wing radiographs were taken in the last exam. A tooth was considered decayed (d) if there

TABLE 1 - Criteria for caries risk assessment and recall visit schedule.

\begin{tabular}{|c|c|c|c|c|c|c|}
\hline \multirow[b]{2}{*}{ Caries risk } & \multicolumn{4}{|c|}{ Risk factors } & \multirow{2}{*}{$\begin{array}{c}\text { Number } \\
\text { of recall } \\
\text { visits }\end{array}$} & \multirow{2}{*}{$\begin{array}{l}\text { Intervals } \\
\text { (days) }\end{array}$} \\
\hline & Tooth cleaning & $\begin{array}{c}\text { Sugar } \\
\text { consumption }\end{array}$ & $\begin{array}{c}\text { Night } \\
\text { bottle-feeding }\end{array}$ & Fluoride* & & \\
\hline High & No & High & Yes & No & 4 & 30 \\
\hline Moderate & Yes & High & No & Yes & 3 & 45 \\
\hline Low & Yes & Low & No & Yes & 2 & 60 \\
\hline
\end{tabular}

*Systemic (water and/or supplement) and/or topic. 
Pereira MBB, Freire MCM. An infant oral health programme in Goiânia-GO, Brazil: results after 3 years of establishment. Braz Oral Res 2004:18(1);12-7.

was visible evidence of a cavity, including untreated dental caries and filled teeth with recurrent caries. White spot lesions were not diagnosed as carious lesions and were not recorded.

\section{Assessment of caries risk}

Caries risk was evaluated in the first visit and at every recall visit. In the present study, only the first and last caries risk (2 to 3 years later) were considered.

\section{Assessment of children's behaviour in the dental office}

Children's behaviour in the dental office was assessed and recorded during the first dental visit and at every recall visit, using Frankl's Scale ${ }^{6}$. Assessment included any dental procedures carried out (examination, preventive procedures and treatment). For the purpose of this part of the study, children were divided into two groups. Group 1 included 45 children enrolled in the programme at ages ranging from 0-7 months, and group 2 included 55 children enrolled at ages 8-12 months.

\section{RESULTS \\ Caries experience}

Table 2 shows caries experience in the first visit to the clinic and after 2 to 3 years in the programme. In the first examination, $99 \%$ of the children were caries-free, and the single child with caries had only one carious tooth (mean $\mathrm{dt}=0.01$ ). No filled or missing tooth due to caries was found. After the follow-up period, only 8 children developed caries. Percentage of caries-free children and mean dft of the overall sample were $91 \%$ and 0.20 , respectively. Only two of those who had caries had dentine lesions.

\section{Caries risk}

Table 3 shows the distribution of the children according to the risk factors for dental caries on the first visit. From birth to 12 months, $86.0 \%$ of the children had never had any oral hygiene procedure, $97.0 \%$ ingested sugar daily, and $22 \%$ had no fluoride exposure. Although the city of Goiannia has been fluoridated since 1985, some of the families still used spring water or other nonfluoridated water sources.

Sugar was almost always added to formula or cow's milk. Among the children who were bottlefed, $94.7 \%$ had sugar added to the bottle. Only four children aged 0-6 months had no added sugar in the bottle, and of these, one was given other sugary foods.

Caries risk for the first and last dental visit is shown in Table 4 . At the first visit, $51 \%$ of the total sample was considered of high, $41 \%$ of moderate and $8 \%$ of low risk. After 2 to 3 years, all but one of the children moved to the moderate and low risk groups (20\% and $79 \%$, respectively), and only $1 \%$

TABLE 2 - Caries experience on first and last examination.

\begin{tabular}{|c|c|c|c|c|c|c|c|c|}
\hline \multirow{2}{*}{$\begin{array}{l}\text { Number } \\
\text { of } \\
\text { children }\end{array}$} & \multicolumn{4}{|c|}{ First examination (first dental visit) } & \multicolumn{4}{|c|}{ Last examination (after 2 to 3 years) } \\
\hline & $\begin{array}{l}\text { Age range } \\
\text { (months) }\end{array}$ & $\begin{array}{c}\text { Mean age } \\
\text { (months) }\end{array}$ & $\begin{array}{l}\text { Caries-free } \\
\text { children (\%) }\end{array}$ & Dt (mean) & $\begin{array}{l}\text { Age range } \\
\text { (months) }\end{array}$ & $\begin{array}{l}\text { Mean age } \\
\text { (months) }\end{array}$ & $\begin{array}{l}\text { Caries-free } \\
\text { children (\%) }\end{array}$ & Ft (mean) \\
\hline 59 & $7-12$ & 9.5 & 58 (98.3) & $1(0.02)$ & $31-48$ & 37.5 & $53(89.8)$ & $11(0.19)$ \\
\hline 100 & $0-12$ & 7.1 & 99 (99.0) & $1(0.01)$ & $24-48$ & 35.4 & $91(91.0)$ & $20(0.20)$ \\
\hline
\end{tabular}

Dt = decayed teeth. $\mathrm{Ft}=$ filled teeth.

TABLE 3 - Risk factors for dental caries on the first dental visit.

\begin{tabular}{|c|c|c|c|c|c|c|c|c|c|c|c|c|}
\hline \multirow{2}{*}{$\begin{array}{c}\text { Age } \\
\text { (months) }\end{array}$} & \multirow{2}{*}{$\begin{array}{l}\text { Number of } \\
\text { children }\end{array}$} & \multicolumn{3}{|c|}{ Feeding practices (\%) } & \multicolumn{2}{|c|}{$\begin{array}{c}\text { Sugar con- } \\
\text { sumption } \\
(\%)\end{array}$} & \multicolumn{2}{|c|}{$\begin{array}{l}\text { Oral hygiene } \\
(\%)\end{array}$} & \multicolumn{4}{|c|}{ Fluoride (\%) } \\
\hline & & $\begin{array}{c}\text { Breast } \\
\text { only }\end{array}$ & $\begin{array}{c}\text { Bottle } \\
\text { only }\end{array}$ & Both & Yes & No & Yes & No & Water & $\begin{array}{l}\text { Supple- } \\
\text { ment }\end{array}$ & Both & None \\
\hline $0-6$ & 41 & 34.1 & 14.6 & 51.2 & 92.7 & 7.3 & 17.1 & 82.9 & 56.1 & 12.2 & 14.6 & 17.1 \\
\hline $7-12$ & 59 & 16.9 & 54.2 & 28.8 & 100.0 & - & 11.9 & 88.1 & 54.2 & 13.6 & 6.8 & 25.4 \\
\hline $0-12$ & 100 & 24.0 & 38.0 & 38.0 & 97.0 & 3.0 & 14.0 & 86.0 & 55.0 & 3.0 & 10.0 & 22.0 \\
\hline
\end{tabular}


Pereira MBB, Freire MCM. An infant oral health programme in Goiânia-GO, Brazil: results after 3 years of establishment. Braz Oral Res 2004:18(1);12-7.

remained at the high risk group.

\section{Children's behaviour in the dental office}

Table 5 shows behaviour of children in the dental office on the first visit, on recall visits and on the final visit. Among those who entered the programme at age 0-7 months (Group 1), the majority $(73.3 \%)$ demonstrated positive behaviour $(\mathrm{C}+\mathrm{D})$ on the first visit, according to Frankl's Scale ${ }^{6}$. However, during the recall visits, when they were aged 8-24 months, only $6.6 \%$ of the children behaved positively. From 25 to 48 months, during their last visit, a higher number of children (64.4\%) showed positive behaviour again.

Among children who entered the programme older, from 8 to 12 months (Group 2), positive behaviour $(\mathrm{C}+\mathrm{D})$ was observed in $18.2 \%$ of them on the first visit, $9.1 \%$ when they were aged 13 24 months, and $76.4 \%$ when they reached 25-48 months (Table 5).

\section{DISCUSSION AND CONCLUSION}

The high number of caries-free children observed after 2 to 3 years of adherence to the programme (91\% of the overall sample), was close to that found among children attending the same programme in the afternoon shift, after 18 to 30 months of follow-up $(93.2 \% \text { caries-free })^{4}$. It was also similar to that reported in other places in Brazil. In Londrina-PR, 93.4\% of the children who attended a similar programme for 1 to 2 years were caries-free ${ }^{22}$. In Recife-PE ${ }^{3}$ and Cambé-PR ${ }^{10}$, these percentages were 93.8 and 92.3, respectively.

Eight children in the present study unexpectedly developed caries during the follow-up period and two of them had dentin lesions. These results suggest that the impact of the programme on the disease incidence was small despite the strategies used, which were based on frequent recall visits and use of preventive methods such as tooth cleaning and topical fluoride. Broader social fac-

TABLE 4 - Caries risk on first and last dental visit.

\begin{tabular}{c|c|c|c|c|c}
\hline \hline \multirow{4}{*}{ First dental visit } & \multirow{2}{*}{ Age (months) } & \multirow{2}{*}{ Number of children } & \multicolumn{3}{|c}{ Caries risk (\%) } \\
\cline { 3 - 6 } & $0-3$ & 20 & High & Moderate & Low \\
\cline { 2 - 5 } & $4-6$ & 21 & 45.0 & 75.0 & 10.0 \\
\cline { 2 - 5 } & $7-12$ & 59 & 66.0 & 43.0 & 14.0 \\
\cline { 2 - 5 } & $0-12$ & 100 & 51.0 & 41.0 & 5.0 \\
\hline \multirow{3}{*}{ Last dental visit } & $25-35$ & 53 & 1.9 & 18.9 & 79.0 \\
\cline { 2 - 6 } & $36-48$ & 47 & - & 21.3 & 78.7 \\
\cline { 2 - 6 } & $25-48$ & 100 & 1.0 & 20.0 & 79.0 \\
\hline \hline
\end{tabular}

TABLE 5 - Children's behaviour in the dental office.

\begin{tabular}{|c|c|c|c|c|c|c|}
\hline & \multirow{2}{*}{$\begin{array}{l}\text { Time of } \\
\text { assessment }\end{array}$} & \multirow{2}{*}{ Age (months) } & \multicolumn{4}{|c|}{ Behaviour* (\%) } \\
\hline & & & A & B & $\mathrm{C}$ & $\mathrm{D}$ \\
\hline \multirow{3}{*}{ Group 1} & First visit & $0-7$ & 13.3 & 13.3 & 11.1 & 62.2 \\
\hline & Recall visits & $8-24$ & 77.8 & 15.6 & 2.2 & 4.4 \\
\hline & Last visit & $25-48$ & 22.2 & 13.3 & 35.5 & 28.9 \\
\hline \multirow{3}{*}{ Group 2} & First visit & $8-12$ & 60.0 & 21.8 & 9.1 & 9.1 \\
\hline & Recall visits & $13-24$ & 69.1 & 21.8 & 7.3 & 1.8 \\
\hline & Last visit & $25-48$ & 12.7 & 10.9 & 20.0 & 56.4 \\
\hline
\end{tabular}

${ }^{*}$ Adapted from Frankl et al. ${ }^{6}$ (1962). A - Definitely negative (--) - refusal of treatment, crying forcefully, fearful or any other overt evidence of extreme negativism. B - Negative (-) - reluctant to accept treatment, uncooperative, some evidence of negative attitude but not pronounced, e.g., sullen, withdrawn. C - Positive (+) - acceptance of treatment; at times cautious, willingness to comply with the dentist, at times with reservation, but patient follows the dentist's directions cooperatively. D - Definitely positive (++) - good rapport with the dentist, interested in the dental procedures, positive laughing and enjoying the situation. 
Pereira MBB, Freire MCM. An infant oral health programme in Goiânia-GO, Brazil: results after 3 years of establishment. Braz Oral Res 2004:18(1);12-7.

tors should therefore be considered as determinants of health status, interacting with biological and behavioural factors. On the other hand, caries prevalence in children aged 24-48 months at the final examination was lower than that found among nursery school children in Brazil in the $1990 s^{9}$. Data from a survey carried out in Goiânia in 1993 showed that $12.7 \%$ of the children aged 2 , $30.1 \%$ of those aged 3 , and $50.5 \%$ of those aged 4 had caries experience ${ }^{7}$.

However, some considerations have to be made regarding such comparisons. The caries scores in the present study would be expected to be lower, since the subjects were enrolled in the Infant Oral Health Programme, while the other Brazilian data report randomized cross-sectional data. In addition, only those children who have successfully remained in the programme were included. It seems likely that parents who felt the importance of this type of programme for their children might be more motivated and more interested in health and prevention than other parents. An adequate control group would therefore provide better support regarding the efficacy of the programme. A study including a control group was recently carried out in a baby clinic of a school in Araçatuba-SP ${ }^{13}$ and the results showed lower levels of enamel caries with cavitation in the study group. However, prevalence of white spot lesions and dentin caries was similar in both groups. A similar study in Chile ${ }^{12}$ showed higher percentage of caries-free children and lower dft in the group enrolled in a preventive dental programme.

One methodological limitation regarding the clinical examination in the present study was the lack of calibration for caries diagnoses. Also, affected tooth surfaces (df-s = decayed or filled surfaces) and white spot lesions were not registered, and could be useful to give more detailed data on caries experience. However, it should be considered that this was not a clinical trial, but an evaluation of a public health programme not designed as such.

Concerning caries risk, there was a dramatic decrease in the number of children in the high risk group, from $51 \%$ to only $1 \%$, after 2 to 3 years in the programme. These findings are supported by previous studies ${ }^{3,4,22}$, and show that unhealthy dietary habits and bad oral hygiene, identified by interview with the mother, can be improved following the advice given in programmes such as this. A major problem, found in the present study, was the very high percentage of children given a bottle with added sugars in their first year. Since breastfeeding is beneficial to general health and also to oral health, mothers and pregnant women should be encouraged to breast-feed. When used, formula and cow's milk should not be sweetened.

One of the objectives of evaluating children's behaviour in the dental clinic was to find out if children who start having dental care at an early age would experience trauma and anxiety at a later age, when they usually start visiting the dentist. Although there has been no indication from previous authors that this may occur, psychologists working in the Department of Health in Goiânia have expressed concern on this point. However, most children in both groups in this study presented positive behaviour after 2 to 3 years in the programme. These findings are similar to those reported by Frankl et al. ${ }^{6}$ (1962) on children aged 3 to 5 who had no previous dental care. In their study, $72 \%$ of the children behaved positively in their initial visit to the dentist. Also, the variations observed with age corroborate previous findings ${ }^{11,20}$. It seems that the results found corresponded to the normal psychology of infants and small children. Before 6 months of age, infants have little awareness of new situations or of strangers, whereas after 6 months they develop apprehensions ${ }^{14}$.

The results of the present study indicate that early dental care through health education and preventive procedures are important factors in gaining and maintaining good dental health. However, these findings should be viewed with caution, given the methodological limitations of the study. Also, further investigations should evaluate the cost-benefit, as well as the effectiveness of the procedures used in this programme. The high use of topical fluoride, for example, should be carefully considered in the light of current knowledge. In addition, maintenance of good dental health throughout life will depend on specific oral health promotion programmes for nurseries and schools, as well as broader measures of public health for whole populations, such as healthy food policies and fluoridation of water.

\section{REFERENCES}

1. Battellino LJ, Cornejo LS, Cattoni STD, Yankilevich ERLM, Calamari SE, Azcura AI. Evaluación del estado de salud

bucodental en preescolares: estudio epidemiológico longitudinal (1993-1994), Córdoba, Argentina. Rev Saúde 
Pereira MBB, Freire MCM. An infant oral health programme in Goiânia-GO, Brazil: results after 3 years of establishment. Braz Oral Res 2004:18(1);12-7.

Pública 1997;31:272-81.

2. Bonecker M, Marcenes W, Sheiham A. Caries reductions between 1995, 1997 and 1999 in preschool children in Diadema, Brazil. Int J Paediatr Dent 2002;12:183-8.

3. Couto GBL, Scavuzzi AIF, Valença MC, Lima MCV, Vasconcelos MMVB, Melo MMD. Avaliação do programa de atenção odontológica precoce - UFPE. An Fac Odont Univ Fed Pernambuco 1998;8:87-95.

4. di Reis IT, Moreira SC. Risco de cárie em bebês. ROBRAC 1995;5:11-7.

5. Figueiredo MC, Rosito DB, Michel JA. Avaliação de 07 anos de um programa odontológico para bebês com bases educativa, preventiva e restauradoras. J Bras Odontopediatr Odontol Bebê 1998;1:33-40.

6. Frankl SN, Shiere FR, Fogels HR. Should the parent remain with the child in the dental operatory? J Dent Child 1962;29:150-63.

7. Freire MCM, Melo RB, Silva SA. Dental caries prevalence in relation to socioeconomic status of nursery school children in Goiânia-GO, Brazil. Community Dent Oral Epidemiol 1996;24:357-71.

8. Freire MCM, Melo RB. Assistência à saúde bucal nas creches de Goiânia-GO. ROBRAC 1996;6:4-8.

9. Freire MCM. Prevalência de cárie e fatores socioeconômicos em pré-escolares: revisão da literatura. Rev Bras Odontol Saúde Coletiva 2000;1:43-9.

10. Gargelini ML, Cezário DMS, Janene CA, Nakagawa MCS, Walter LRF. Avaliação do programa de Odontologia para bebês no município de Cambé. Saúde em Debate 1991;32:75-7.

11. Goepferd SJ. An infant oral health program: the first 18 months. Pediatr Dent 1989;79:21-5.

12. Gomez SS, Weber AA. Effectiveness of a caries preventive program in pregnant women and new mothers on their offspring. Int J Paediatr Dent 2001;11:117-22.

13. Melhado FL. Influência do atendimento odontológico para bebês sobre a prevalência da cárie dentária: estudo comparativo [Dissertação de Mestrado]. Araçatuba: Faculdade de Odontologia da UNESP; 2000.

14. Mussen PH, Conger JJ, Kagan J, Huston AC. Child development and personality. $6^{\text {th }}$ ed. New York: Harper $\&$ Row; 1984.

15. Nowak AJ. Rationale for the timing of the first oral evaluation. Pediatr Dent 1997;19:8-11.

16. Pinto VG. Estudo epidemiológico sobre prevalência da cárie dental em crianças de 3 a 14 anos. Brasil, 1993. Brasília: SESI-DN; 1996.

17. Pitts NB, Evans DJ, Nugent ZJ. The dental caries experience of 5-year-old children in Great Britain. Surveys coordinated by the British Association for the Study of Community Dentistry in 1999/2000. Community Dent Health 2001;18:49-55.

18. Ramos-Gomez F, Jue B, Bonta CY. Implementing an infant oral care program. J Calif Dent Assoc 2002;30:75261.

19. Reisine ST, Douglass JM. Psychosocial and behavioral issues in early childhood caries. Community Dent Oral Epidemiol 1998;26:32-44.

20. Torriani DD. Análise do comportamento de bebês durante atendimento odontológico: relação entre sexo, idade e dentes irrompidos [Dissertação de Mestrado]. Araçatuba: Faculdade de Odontologia da UNESP; 1999.

21. Walter LRF, Ferelle A, Issao M. Odontologia para o bebê. São Paulo: Artes Médicas; 1996.

22. Walter LRF, Nakama R. Prevenção da cárie dentária através da identificação, determinação e controle dos fatores de risco em bebês - Parte 1. J Bras Odontopediatr Odontol Bebê 1998;1:91-100. 